\title{
The Needs of Islamic Digital Resources in Polytechnic Brunei Darussalam: A Preliminary Study
}

\author{
Aliff Nawi \\ School of Education, Universiti Utara Malaysia, Malaysia, aliffnawi@yahoo.com
}

Gamal Abdul Nasir Zakaria

Sultan Hassanal Bolkiah Institute of Education, Universiti Brunei Darussalam, Brunei, gamal.zakaria@ubd.edu.bn

\section{Norkhairiah Hashim}

Halalan Thayyiban Research Centre, University Islam Sultan Sharif Ali, Brunei, norkhairiah.hashim@gmail.com

\section{Salwa Mahalle}

Sultan Hassanal Bolkiah Institute of Education, Universiti Brunei Darussalam, Brunei, salwa.mahalle@ubd.edu.bn

\section{Chua Chy Ren}

School of Education, Universiti Utara Malaysia, Malaysia, chy_ren1987@hotmail.com

\begin{abstract}
The aim of this study is to identify and analyze the potential usage of Islamic Digital Resources in Polytechnic Brunei Darussalam. This research focus on identifying certain aspects which are (1) types of mobile device used; (2) learning activities that often used in mobile devices; (3) types of social media application favors by student; (4) determining most preferred method of teaching, and; (5) potential use of Islamic Digital Resources. The study uses quantitative approach through survey instrument (questionnaire) that involves 50 students. The data is analyzed using descriptive statistic (percentage frequency distribution and min). Findings show that the potential to create Islamic Digital Resources in Polytechnic is promising. This is based on the compatibility of mobile devices own by students, the familiarity in doing learning activities in mobile devices and willingness to learn through digital. The conclusion is Islamic Digital Resources in Polytechnic is suitable to be developed and applied in teaching and learning. At the end of the study, a few issues regarding the usage of Islamic Digital Resources has been discussed.
\end{abstract}

Keywords: need analysis, digital resources, Islamic resources, polytechnic, Brunei 


\section{INTRODUCTION}

The establishment of Polytechnic Brunei Darussalam in 2012 has been one of the efforts by Ministry of Education to provide opportunities to ' $A$ ' level leavers, college leavers and technical and vocational school leavers by providing a path to achieve higher level skillset. In conjunction with the needs and requirements of Brunei Darussalam to accelerate and increase development and progress in manpower resources, therefore the establishment of Polytechnic Brunei Darussalam is the main attention in National Development Plan in order to achieve Brunei Vision 2035.

All of this effort is in lieu with the purpose of the implementation of the 21st Century National Educational System (SPN-21) and through the efforts to increase this opportunity, it is anticipated to produce proficient and knowledgeable workforce in conjunction with current developing technology. Various courses such as Accounting, Financing, Management, Marketing and Entrepreneurship, Computer Networking, Information System and Technology, Web Computerization and Interior Designing are introduced in accordance with Ministry of Education Strategic Plan to achieve the industrial needs for the purpose of national development as well as fulfilling the implementation demand of the 21st Century SPN-21 which is to prepare better articulation path between General Education and Technical and Vocational Education.

The courses offered are intended to encourage students to venture into high level of practical skill field via teaching and learning which applies 21 st century skill aspect solely to increase their workability in going through competitive work life and simultaneously equipped to face with global economy challenge. According to (AbdRahman, 2012), programs offered are of high quality, consist of relevant curriculum and effective presentation aims to produce highly skilled workforce and attaining the nation's need to face with dynamic global challenge. Therefore, efforts to increase quality of curriculum and teaching and learning methods have to be enhanced in view with current development.

\section{STUDY BACKGROUND}

In 21st Century National Education System (SPN 21), Islamic Study is placed in core subject category. Other than providing students with ukhrawi knowledge and duniawi knowledge or in other words fardhu ain knowledge and fardhu kifayah knowledge, Islamic Study also needs to develop students' skills especially 21 st century skills to prepare them for current change and current advancement in information and technology.

Islamic Study is more effective if its function and role is to be enhanced to move towards development of skilled generation. This is consistent with ongoing and previous efforts by Brunei Darussalam Ministry of Education as stated in curriculum framework of SPN 21. One of the efforts is to build lifetime learning skill and provide the students with high value skills or marketable skills (Curriculum Development Department, 2009).

This situation means teachers will need a new approach, for example the usage of computer technology and ICT as medium between teachers and students. This method 
not only facilitates the teachers but also attracting the students to further understand a certain subject. Through this approach, teachers will gain benefits such as computer and ICT knowledge, and further to that they can apply in teaching in class which is more interactive and modern. If in the past, teaching \& learning is more to chalk and blackboard, now teaching \& learning is recognized by combination of projector, LCD, courseware or web portal.

Since then, various sources which are based on multimedia are developed to help with students' learning. Among teaching and learning with ICT based are subjects such as Science (Clark \& Mayer, 2012), Mathematics (Genlott \& Grönlund, 2016), English (Mehring, 2017), History (Taharim, Lokman, Isa, \& Noor, 2016) and few other subjects. The same goes to ICT usage in Islamic Study. However, findings in study of ICT effectiveness in Islamic Study subject are still in unsatisfactory level (Mohd Aderi Che Noh \& Rohani Ahmad Tarmizi, 2009; Aliff Nawi \& Zakaria, 2016; Mohd Aliff Mohd Nawi \& Ramlan, 2014; Gamal Abdul Nasir Zakaria, Kamis, Mahalle, \& Nawi, 2014). It shows that ICT usage in teaching and learning of Islamic Study is still not optimized on the whole.

Therefore, appropriate and relevant curriculum or educational content is imperative to support teaching and learning in 21 st century. Usage exploration of Islamic Digital Resources has to be conducted so that the need for the resources can be identified. Meanwhile teachers are the main social agent and have the important role to be proactive and productive in executing tasks and responsibility as a teacher. Particularly in generating skill generatively and explicitly through Islamic Study subject.

\section{Research Objective}

Analysis study of the needs of Islamic Digital Resources is conducted to achieve a few study objectives. Among others are:

1. To identify what are the mobile devices owned.

2. To identify what are the learning activities conducted in mobile devices.

3. To identify which media social application is the choice of the students.

4. To identify the students' assessment towards preferred teaching methods.

5. To identify the students' readiness towards the usage of Islamic Digital Resources.

\section{METHOD}

In this preliminary study, the researchers will use a survey questionnaire as a research instrument. The questionnaire distributed was divided into few segments which are: a) Background Demographic. b) Types of telephone used. c) Mobile phone usageDuration of mobile phone usage and application d) Learning activities- Perception towards the usage of mobile phones in teaching and learning, and: e) Readiness LevelReadiness level of teachers towards the usage of mobile phones as learning tool. This instrument has been adopted from Nawi, Hamzah, and Abdul Rahim (2015). A totally of 
50 Polytechnic students were chosen by purposive sampling. After the questionnaires were collected, the data is keyed into the SPSS software and analyzed descriptively.

\section{FINDINGS}

Study findings are divided into few categories. 1) types of mobile devices used, 2) learning activity in mobile devices, 3) frequency of media social usage, 4) learning method preferred, and 5) level of acceptance of Islamic Digital Resources usage.

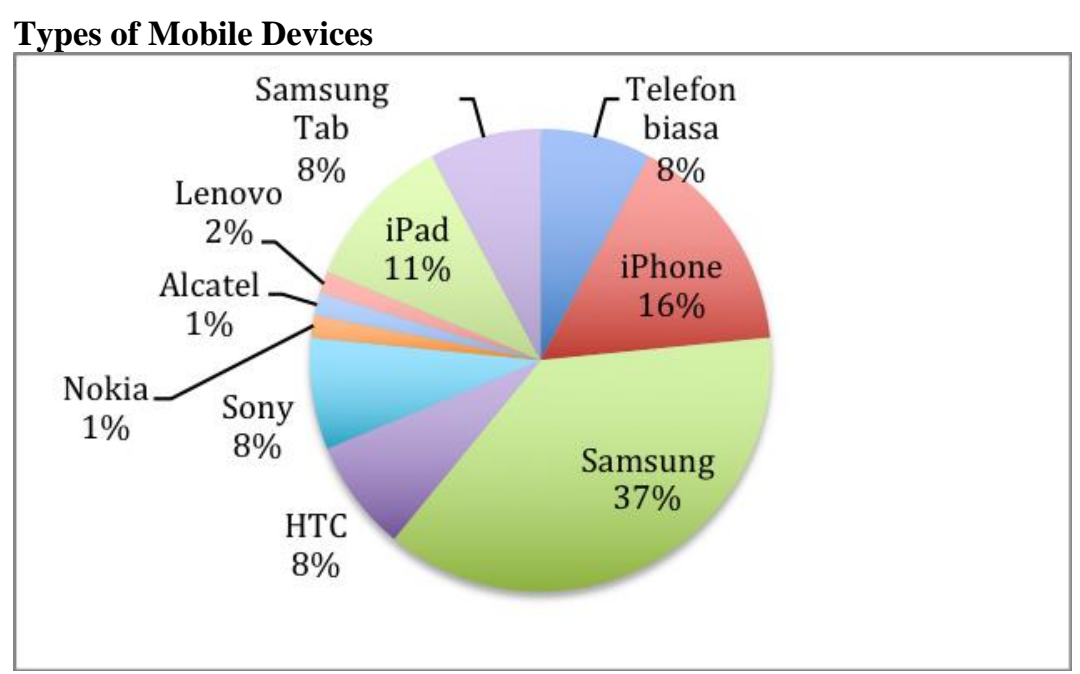

Figure 1

Mobile Devices Brand

Figure 1 above shows percentage of mobile devices category owned by students $(\mathrm{n}=50)$. $37 \%$ of students are using Samsung which made up the majority of telephone brand compared to other brands. Iphone users made up $16 \%$ which contributes to second highest. Followed by iPad users which are $11 \%$. Meanwhile, normal phone users (No 3G), HTC, Samsung Tab and Sony has the even numbers of quantity which is representing $8 \%$. Lenovo brand users have the score of $2 \%$, Alcatel and Nokia each contributes to $1 \%$. Table 1 below shows category of mobile devices in more detail. 


\section{Learning Activities}

Table 1

Learning Activities in Mobile Devices

\begin{tabular}{llllllll}
\hline No & Item & \multicolumn{3}{l}{ Percentage $(\%)(f)$} & & & Mean \\
& & 1 & 2 & 3 & 4 & 5 & \\
\hline B1 & \multirow{2}{*}{ Audio recording. } & 32 & 42 & 14 & 12 & - & 2.06 \\
& & $(16)$ & $(21)$ & $(7)$ & $(6)$ & & \\
\hline B2 & \multirow{2}{*}{ Video recording. } & 28 & 28 & 26 & 16 & 2 & 2.36 \\
& & $(14)$ & $(14)$ & $(13)$ & $(8)$ & $(1)$ & \\
\hline B3 & \multirow{2}{*}{ Typing note. } & 4 & 16 & 32 & 26 & 22 & 3.46 \\
& & $(2)$ & $(8)$ & $(16)$ & $(17)$ & $(11)$ & \\
\hline B4 & \multirow{2}{*}{ Sending SMS to lecturer. } & 8 & 24 & 40 & 22 & 6 & 2.94 \\
& & $(4)$ & $(12)$ & $(20)$ & $(11)$ & $(3)$ & \\
\hline B5 & \multirow{2}{*}{ Sending SMS to friends. } & 2 & 2 & 20 & 22 & 54 & 4.24 \\
& Discussing with lecturer via social media & 14 & $(1)$ & $(10)$ & $(11)$ & $(27)$ & \\
\hline B6 & Dis & 28 & 24 & 20 & 14 & 2.92 \\
& (Facebook/ Whatsapp/ Viber/ WeChat/ etc) & $(7)$ & $(14)$ & $(12)$ & $(10)$ & $(7)$ & \\
\hline B7 & Discussing with friends via social media & - & 4 & 12 & 20 & 64 & 4.44 \\
& (Facebook/ Whatsapp/ Viber/ WeChat/ etc) & & $(2)$ & $(6)$ & $(10)$ & $(32)$ & \\
\hline B8 & Reading source of reference in the Internet & - & 2 & 36 & 28 & 34 & 3.94 \\
& (Pdf/ Words/ Slide) via offline & & $(1)$ & $(18)$ & $(14)$ & $(17)$ & \\
\hline B9 & Finding reference sources from the Internet & - & - & 6 & 32 & 62 & 4.56 \\
& (Website/ Blog/ etc) & & & $(3)$ & $(16)$ & $(31)$ & \\
\hline Total & & & & & & & 3.43 \\
\hline
\end{tabular}

Table 2 above displays various learning activities conducted in mobile devices. Generally, overall finding indicated that the mean score is low $(\min =3.43)$. Researcher has identified that there are two items which has influenced the low mean namely item B1 and B2. B1 item is associated to audio recording activity meanwhile B2 is associated to learning video recording. Both of the items get the lowest score $(\mathrm{B} 1=2.06)$ and $(\mathrm{B} 2=2.36)$. Both of the items also indicated that recording audio and recording video are not the daily practice among students.

The same goes to items B4 and B6 which are associated to sending SMS to lecturer and discussing with lecturer using social media application in mobile devices. The score for both items can be considered as low (B4=2.94 / B6=2.92) which shows that not many students use mobile devices to ask questions to lecturer. On the other hand, they are perceived as prefer and keen to use mobile devices to discuss with friends via SMS $(B 5=4.24)$ and via media social application like Facebook, Whatsapp and Viber (B7=4.44).

Additionally, it is presumed that on this early stage of study the students prefer to obtain reference source from the internet. This can be observed by a very high score acquired by item B9 which is 4.56 . Other than that, students are also interested in reading in mobile devices with the attained score of 3.94 (B8). The conclusion is, mobile devices have the potential to be the source of learning based on learning activities practiced by the students. 


\section{Social Media Usage}

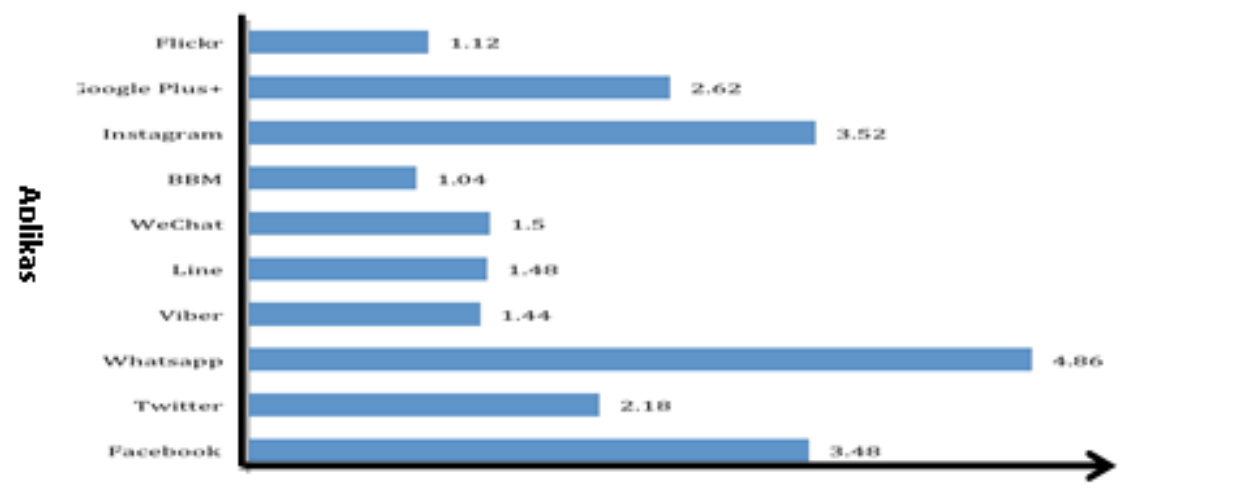

Figure 2

Social Media Application Usage

Figure 2 above shows mean score of social media application usage in mobile devices. Finding shows that Whatsapp is the most frequently used application (min=4.86) compared to other applications. Instagram application achieved second highest score which is 3.48 followed by Facebook application with mean score of 3.48. Google Plus+ application and Twitter each has a mean score of 2.62 and 2.18. The rest which are Flickr, BBM, WeChat, Line and Viber application has the mean score of 1.04-1.44 indicates that these applications are rarely used by the students.

\section{Assessment of Current Teaching Method}

Table 3

Assessment of Current Teaching Method

\begin{tabular}{|c|c|c|c|c|c|c|c|}
\hline \multirow[t]{2}{*}{ No } & \multirow[t]{2}{*}{ Item } & \multicolumn{5}{|c|}{ Frequency $(\%)(f)$} & \multirow[t]{2}{*}{ Mean } \\
\hline & & 1 & 2 & 3 & 4 & 5 & \\
\hline E1 & Lecture/course explanation & - & - & $\begin{array}{l}30 \\
(15)\end{array}$ & $\begin{array}{l}46 \\
(23)\end{array}$ & $\begin{array}{l}24 \\
(12)\end{array}$ & 3.94 \\
\hline E2 & Q\&A & $\begin{array}{l}4 \\
(2)\end{array}$ & $\begin{array}{l}24 \\
(12)\end{array}$ & $\begin{array}{l}32 \\
(16)\end{array}$ & $\begin{array}{l}30 \\
(15)\end{array}$ & $\begin{array}{l}10 \\
(5)\end{array}$ & 3.18 \\
\hline E3 & Group discussion & - & $\begin{array}{l}4 \\
(2)\end{array}$ & $\begin{array}{l}28 \\
(14)\end{array}$ & $\begin{array}{l}26 \\
(13)\end{array}$ & $\begin{array}{l}42 \\
(21)\end{array}$ & 4.06 \\
\hline E5 & Doing assignment & $\begin{array}{l}2 \\
(1)\end{array}$ & $\begin{array}{l}10 \\
(5)\end{array}$ & $\begin{array}{l}36 \\
(18)\end{array}$ & $\begin{array}{l}32 \\
(16)\end{array}$ & $\begin{array}{l}10 \\
(10)\end{array}$ & 3.58 \\
\hline E6 & Website surfing & - & $\begin{array}{l}4 \\
(2)\end{array}$ & $\begin{array}{l}22 \\
(11)\end{array}$ & $\begin{array}{l}28 \\
(14)\end{array}$ & $\begin{array}{l}46 \\
(23)\end{array}$ & 4.16 \\
\hline E7 & Watching movie/video & - & $\begin{array}{l}6 \\
(3) \\
\end{array}$ & $\begin{array}{l}30 \\
(15)\end{array}$ & $\begin{array}{l}34 \\
(17)\end{array}$ & $\begin{array}{l}30 \\
(15)\end{array}$ & 3.88 \\
\hline E8 & $\begin{array}{l}\text { Project implementation } \\
\text { (individually) }\end{array}$ & - & $\begin{array}{l}16 \\
(8)\end{array}$ & $\begin{array}{l}36 \\
(18)\end{array}$ & $\begin{array}{l}36 \\
(18)\end{array}$ & $\begin{array}{l}12 \\
(6)\end{array}$ & 3.44 \\
\hline E9 & $\begin{array}{l}\text { Project implementation (by } \\
\text { group) }\end{array}$ & - & $\begin{array}{l}6 \\
(3)\end{array}$ & $\begin{array}{l}32 \\
(16)\end{array}$ & $\begin{array}{l}30 \\
(15)\end{array}$ & $\begin{array}{l}32 \\
(16)\end{array}$ & 3.88 \\
\hline Total & & & & & & & 3.76 \\
\hline
\end{tabular}


Table 3 above shows various methods that were implemented in the classroom. Overall, majority of the students prefer learning method via website surfing (min=4.16). Group discussion method (E3) also has a high mean score which is 4.06. Lecture/course explanation (E1) still is the students' choice with mean score of 3.94. Meanwhile learning method via movie or video attained a mean score of 3.88 .

Other than that, in the early stage of study, it is figured that the students prefer to execute projects by group $(\mathrm{min}=3.88)$ compared with individually $(\mathrm{min}=3.44)$. The rest of it which is item E5 is related to doing assignment has a mean score of 3.58. While question and answer (Q\&A) method (E2) has the lowest mean score compared to other methods which is 3.18 .

\section{Potential of Islamic Digital Resources Usage}

Table 4

Potential of Islamic Digital Resources

\begin{tabular}{llll}
\hline \multicolumn{1}{c}{ Item } & Scale & Frequency $(f)$ & Percentage $(\%)$ \\
\hline I want to learn at anytime & Yes & 39 & 78 \\
& No & 11 & 22 \\
\hline I want to learn anywhere & Yes & 40 & 80 \\
& No & 10 & 20 \\
\hline I want to complete my assignment anytime & Yes & 42 & 84 \\
& No & 8 & 16 \\
\hline I want to make mobile devices as learning tool & Yes & 46 & 92 \\
& No & 4 & 8 \\
\hline I want to use social media as discussion platform & Yes & 47 & 94 \\
& No & 3 & 6 \\
\hline If Islamic Study learning materials were designed & Facebook & 8 & 16 \\
in the Mobile Portal, which social media would & Twitter & 2 & 4 \\
be the choice & Whatsapp & 28 & 56 \\
& Line & - & - \\
& Blog Forum & 12 & 24 \\
\hline
\end{tabular}

Table above shows the potential of Islamic Digital Resources. Overall, students gave good response towards all the listed items. This matter can be observed through an agreement score finding that is more than $78 \% .78 \%$ of the students agree to learn at any time and $22 \%$ students opposed to this. $80 \%$ of the students agree to learn anywhere while $20 \%$ didn't want to learn anywhere. $84 \%$ of the students agree to complete their assignment at any time while $16 \%$ of students are saying otherwise.

Majority of the respondents approved on the agreement item to make mobile devices as learning tool with the score of $92 \%$. While $94 \%$ of respondents agree to use social media (Faceboook/Whatsapp/Viber/WeChat/etc) as one of discussion platform. The choice of social media shows students agree to choose Whatapp application compared to other applications. This matter can be observed through score of 56\% achieved. Blog and Forum has a score of $24 \%$ followed by Facebook which is $16 \%$. Twitter application has a low score of $4 \%$ while Line and SMS (Short Messaging System) application didn't have any score at all. Figure below shows overall respondents' choice of media social application as the online discussion platforms. 


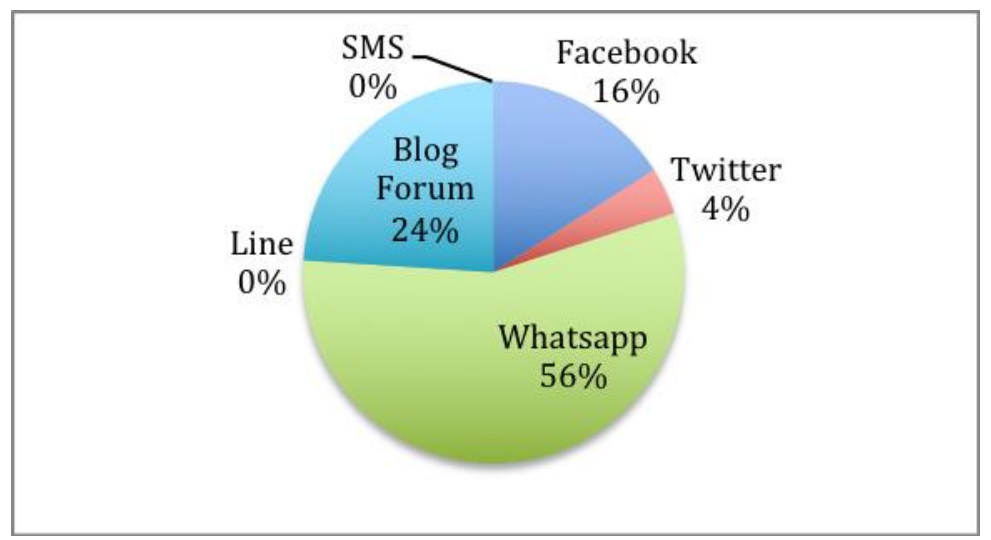

Figure 3

The Chosen Media Social applications as discussion platform

\section{DISCUSSION}

Generally, this study was done to identify the potential of Islamic Digital Resources in Brunei Darussalam Polytechnic. Digital Resources is one of the information and communication technology (ICT) sources that connect students with various information in the cyber world. Through facilities provided by ICT, students can explore borderless information only with few clicks of the mouse or touch of the screen on their own mobile phone.

This scenario explains that teacher is not the only main source of information and only plays the role as facilitator. Since the thriving of globalization, with the presence of internet information searching is observed as very easy. Moreover Zakaria, Tajudeen, Nawi, and Mahalle (2014) and Nawi, Jamsari, Hamzah, Sulaiman, \& Umar (2012) explains that Islamic Study field has also been undergoing drastic change with the existence of online video like YouTube, free website and more. This facility is used by many Muslim users to upload information about Islam to be conveyed online. This information will be accessed by the whole world via computer or mobile devices like smart phone, tablet, iPad and such.

On the other hand, students are observed to be keen on online discussion with friends via media social application such as Whatsapp and Facebook. According to Yeboah and Ewur (2014), social media application attracts students because it is more user friendly, easier to share ideas and information is delivered faster in the network. Otherwise, students are not interested to discuss with lecturers neither using media social application nor conventional method.

Finding of learning method preferred also showing that students are more attracted to mobile learning concept. Mobile learning concept has the characteristics of anytime and anywhere by using smart phone tablet or pocket PC. Through the usage of m-learning method, learning process not only focused on one platform or limited in the classroom 
but, mobile learning is more categorized as just-in-time, just-in-case, on-the-move and on-demand (Neyem, Ochoa, Pino, \& Franco, 2012). This shows that the usage of mobile devices is making learning happens anytime and anywhere compared to the usage of notebook which is prone to damage and does not last long (A. Nawi et al., 2015). This situation shows that mobile devices have more benefits compared to conventional resources.

\section{CONCLUSION AND SUGGESTIONS}

This study is conducted to view the potential use of Islamic Digital Resources in Polytechnic Brunei Darussalam. Suggestion to develop these digital resources is to implement learning element by 21 st Century and to complement the learning method by using the mobile way. The integration of digital resources usage in Islamic Study is expected to assist teachers and encourage learning at all time.

Based on analyzed finding, it is presumed that the need to build an Islamic Digital Resources is very positive. Moreover, learning environment that is complemented by internet and wifi facilities will make this suggestion a success. It is undeniable that there are the needs to overcome obstacles when developing this resources. Especially concerning content adaptation and technical issues.

Therefore, suggestion to build an Islamic Digital Resources in Polytechnic will be realized in line with current learning needs. The students' need, attitude and tendency should also be taken into account when developing the resources. Besides that, theory and learning strategies have to be adapted with students' learning method via online. It is anticipated that suggestion to build Islamic Digital Resources will boost and give new life in teaching and learning of Islamic Study.

\section{REFERENCES}

Abd-Rahman, J. (2012). Politeknik Brunei sediakan peluang lebih luas ke tahap kemahiran tinggi. Berita Pelita Brunei.

Clark, R. C., \& Mayer, R. E. (2012). e-Learning and the science of instruction: Proven guidelines for consumers and designers of multimedia learning. John Willey \& Sons.

Curriculum Development Department. (2009). In Jabatan Perkembangan Kurikulum, Kementerian Pendidikan, Negara Brunei Darussalam.

Genlott, A. A., \& Grönlund, A. (2016). Closing the gaps - Improving literacy and mathematics by ict-enhanced collaboration. Computers and Education, 99, 68-80. https://doi.org/10.1016/j.compedu.2016.04.004.

Mehring, J. (2017). The flipped classroom. In J. Mehring, \& A. Leis (Eds.), Innovations in flipping the language classroom (pp.1-9). Singapore: Springer.

Mohd Aderi Che Noh \& Rohani Ahmad Tarmizi. (2009). Persepsi Pelajar Terhadap Amalan Pengajaran Tilawah Al-Quran ( Students' Perception Toward Teaching Tilawah Al-Quran ). Jurnal Pendidikan Malaysia. 
Nawi, A., Hamzah, M. I., \& Abdul Rahim, A. A. (2015). Teachers acceptance of mobile learning for teaching and learning in islamic education: A preliminary study. Turkish Online Journal of Distance Education, 16(1), 184-192. https://doi.org/10.17718/tojde.30611.

Nawi, A., \& Zakaria, G. A. N. (2016). Pembangunan dan penilaian portal IPBL Di politeknik Brunei. Malaysian Journal of Communication, 32(1), 415-444. https://doi.org/ 10.17576/JKMJC-2016-3201-20.

Nawi, M. A. M., Jamsari, E. A., Hamzah, M. I., Sulaiman, A., \& Umar, A. (2012). The impact of globalization on current islamic education. Australian Journal of Basic and Applied Sciences, 6(8), 74-78.

Nawi, Mohd Aliff Mohd, \& Ramlan, Y. (2014). A study on the straregis and practice of teaching among trainee teachers during teaching training. The Online Journal of Islamic Education, 2(1), 1-6.

Neyem, A., Ochoa, S. F., Pino, J. A., \& Franco, R. D. (2012). A reusable structural design for mobile collaborative applications. Journal of Systems and Software, 85(3), 511-524. https://doi.org/10.1016/j.jss.2011.05.046.

Taharim, N. F., Lokman, A. M., Isa, W. A. R. W. M., \& Noor, N. L. M. (2016). Investigating feasibility of mobile learning (M-learning) for history lesson. In $\mathrm{O}$. Hassan, S. Abidin, R. Legino, R. Anwar, \& M. Kamaruzaman (Eds.), International colloquium of art and design education research (i-CADER 2014) (pp.541-550). Singapore: Springer.

Yeboah, J., \& Ewur, G. D. (2014). The impact of Whatsapp messenger usage on students performance in tertiary institutions in Ghana. Journal of Education and Practice, 5(6), 157-164.

Zakaria, G. A. N., Tajudeen, A. L., Nawi, A., \& Mahalle, S. (2014). Re-engineering values into the youth education system: A needs analysis study in Brunei Darussalam. International Education Studies, 7(5), 15-24.

Zakaria, Gamal Abdul Nasir, Kamis, H., Mahalle, S., \& Nawi, A. (2014). Leadership style of religious school headmasters and its relationship to academic achievement in Brunei Darussalam. Asian Social Science, 10(3), 112119. 